\title{
Reconstruction of Holocene vegetation dynamics at Lac de Bretaye, a high-mountain lake in the Swiss Alps
}

\begin{tabular}{|c|c|}
\hline Journal: & The Holocene \\
\hline Manuscript ID: & HOL-15-0047.R1 \\
\hline Manuscript Type: & Paper \\
\hline Date Submitted by the Author: & 08-Jul-2015 \\
\hline Complete List of Authors: & $\begin{array}{l}\text { Thöle, Lena; Institute of Plant Sciences and Oeschger Centre for Climate } \\
\text { Change Research, University of Bern, ; Institute of Geological Sciences and } \\
\text { Oeschger Centre for Climate Change Research, University of Bern, } \\
\text { Schwörer, Christoph; Institute of Plant Sciences and Oeschger Centre for } \\
\text { Climate Change Research, University of Bern, } \\
\text { Colombaroli, Daniele; Institute of Plant Sciences and Oeschger Centre for } \\
\text { Climate Change Research, University of Bern, } \\
\text { Gobet, Erika; Institute of Plant Sciences and Oeschger Centre for Climate } \\
\text { Change Research, University of Bern, } \\
\text { Kaltenrieder, Petra; Institute of Plant Sciences and Oeschger Centre for } \\
\text { Climate Change Research, University of Bern, } \\
\text { van Leeuwen, Jacqueline; Institute of Plant Sciences and Oeschger Centre } \\
\text { for Climate Change Research, University of Bern, } \\
\text { Tinner, Willy; Institute of Plant Sciences and Oeschger Centre for Climate } \\
\text { Change Research, University of Bern, }\end{array}$ \\
\hline Keywords: & $\begin{array}{l}\text { palynology, Ulmus, mountain vegetation, afforestation, forest diversity, } \\
\text { human impact }\end{array}$ \\
\hline Abstract: & $\begin{array}{l}\text { A deeper understanding of past vegetation dynamics is required to better } \\
\text { assess future vegetation responses to global warming in the Alps. Lake } \\
\text { sediments from Lac de Bretaye, a small subalpine lake in the Northern } \\
\text { Swiss Alps ( } 1780 \mathrm{~m} \text { a.s.I.), were analysed to reconstruct past vegetation } \\
\text { dynamics for the entire Holocene, using pollen, macrofossil and charcoal } \\
\text { analyses as main proxies. The results show that timberline reached the } \\
\text { lake's catchment area at around } 10300 \text { cal. BP, supporting the hypothesis } \\
\text { of a delayed postglacial afforestation in the Northern Alps. At the same } \\
\text { time, thermophilous trees such as Ulmus, Tilia and Acer established in the } \\
\text { lowlands and expanded to the altitude of the lake, forming distinctive } \\
\text { boreo-nemoral forests with Betula, Pinus cembra and Larix decidua. From } \\
\text { about } 5000 \text { to } 3500 \text { cal. BP, thermophilous trees declined due to increasing } \\
\text { human land use, mainly driven by the mass expansion of Picea abies and } \\
\text { severe anthropogenic fire activity. From the Bronze Age onwards (c. } 4200- \\
2800 B P \text {, grazing indicators and high values for charcoal concentration and } \\
\text { influx attest an intensifying human impact, fostering the expansion of } \\
\text { Alnus viridis and Picea abies. Hence, biodiversity in alpine meadows } \\
\text { increased whereas forest diversity declined, as can be seen in other } \\
\text { regional records. We argue that the anticipated climate change and }\end{array}$ \\
\hline
\end{tabular}


decreasing human impact in the Alps today will not only lead to an upward movement of timberline with consequent loss of area for grasslands, but also to a disruption of Picea abies forests, which may allow the reexpansion of thermophilous tree species.

\section{SCHOLARONE ${ }^{\text {m }}$}

Manuscripts 
Lena Thöle ${ }^{1,2}$, Christoph Schwörer ${ }^{1}$, Daniele Colombaroli ${ }^{1}$, Erika Gobet ${ }^{1}$, Petra

Kaltenrieder1, Jacqueline van Leeuwen ${ }^{1}$, Willy Tinner ${ }^{1}$

${ }^{1}$ Paleoecology, Institute of Plant Sciences and Oeschger Centre for Climate Change Research, University of Bern, Altenbergrain 21, CH-3013 Bern, Switzerland

${ }^{2}$ Institute of Geological Sciences and Oeschger Centre for Climate Change Research, University of Bern, Baltzerstrasse 1+3, CH-3012 Bern, Switzerland

Corresponding author: Lena Thöle, Institute of Geological Sciences and Oeschger Centre for Climate Change Research, University of Bern, Baltzerstrasse 1+3, CH 3012 Bern, Switzerland

Email: lena.thoele@geo.unibe.ch

\begin{abstract}
A deeper understanding of past vegetation dynamics is required to better assess future vegetation responses to global warming in the Alps. Lake sediments from Lac de Bretaye, a small subalpine lake in the Northern Swiss Alps (1780 m a.s.1.), were analysed to reconstruct past vegetation dynamics for the entire Holocene, using pollen, macrofossil and charcoal analyses as main proxies. The results show that timberline reached the lake's catchment area at around $10300 \mathrm{cal}$. BP, supporting the hypothesis of a delayed postglacial afforestation in the Northern Alps. At the same time, thermophilous trees such as Ulmus, Tilia and Acer established in the lowlands and expanded to the altitude of the lake, forming distinctive boreo-nemoral forests with Betula, Pinus cembra and Larix decidua. From about 5000 to 3500 cal. BP,
\end{abstract}


thermophilous trees declined due to increasing human land use, mainly driven by the mass expansion of Picea abies and severe anthropogenic fire activity. From the Bronze Age onwards (c. 4200-2800 cal. BP), grazing indicators and high values for charcoal concentration and influx attest an intensifying human impact, fostering the expansion of Alnus viridis and Picea abies. Hence, biodiversity in alpine meadows increased whereas forest diversity declined, as can be seen in other regional records. We argue that the anticipated climate change and decreasing human impact in the Alps today will not only lead to an upward movement of timberline with consequent loss of area for grasslands, but also to a disruption of Picea abies forests, which may allow the re-expansion of thermophilous tree species.

\section{Keywords}

Palynology, Ulmus, mountain vegetation, afforestation, forest diversity, human impact 
Assessing possible ecosystem responses to global warming is one of the most important challenges concerning climate change. Especially mountain ecosystems are extremely vulnerable due to highly adapted species, limited space for migration and steep ecological gradients (IPCC, 2014). The expected increase in temperature of $3-5^{\circ} \mathrm{C}$ by the end of this century may lead to a marked shift in vegetation ranges, habitat losses and a rigorous decrease in today's exceptionally high biodiversity in alpine regions (CH2011, 2011; IPCC, 2013). Being one of the most distinctive ecological boundaries in the Alps, the treeline ecotone is expected to react very sensitively to temperature changes (Körner, 2003, 2012). Thus, rising temperatures will lead to an upward movement of treeline and timberline - a trend that can be observed already today in different mountain areas around the world (Gehrig-Fasel et al., 2007; Harsch et al., 2009; Leonelli et al., 2011).

However, predicting persevering future responses of vegetation to a changing climate requires an understanding of species responses over long periods of time. Here, paleoecological analysis serves as a prime tool to investigate long-term vegetation dynamics in the past. Reconstructions of past treeline dynamics have shown important changes in the structure and position of the treeline ecotone over time (e.g. Tinner and Theurillat, 2003; Wick et al., 2003; Gobet et al., 2005; Tinner and Kaltenrieder, 2005; Lotter et al., 2006; Schwörer et al., 2014a). For instance, the rapid (50-100years) afforestation at the end of the Younger Dryas cold phase (c. 11700 cal. BP, Schwander et al., 2000) that followed a temperature increase of $2-4^{\circ} \mathrm{C}$ (Ammann et al., 2000; Schwander et al., 2000) can be used as analogue to the expected temperature changes within this century.

Paleoecological studies in the Alps can also help to understand how human impact has shaped alpine landscapes for thousands of years, since the Neolithic (c. $7500 \mathrm{cal}$. BP, 
e.g. Tinner et al., 1996; Wick et al., 2003; Gobet et al., 2003; Valsecchi et al., 2010; Schwörer et al., 2014a; Rey et al., 2013). For instance, timberline was lowered by about $300 \mathrm{~m}$ due to logging, grazing and burning activities by early settlers (e.g. Tinner and Theurillat, 2003), a process much in contrast with nowadays' land use abandonment in the Alps (MacDonald, 2000), which is causing a re-advance of the forest (Theurillat and Guisan, 2001; Gehrig-Fasel et al., 2007). Hence, treeline dynamics are strongly affected by both climate and land use, and disentangling the two drivers' relative importance in the past may help to better evaluate predicted changes and their impacts (e.g. Hoiss et al., 2013).

Besides affecting timberline positions, early anthropogenic influence also had an impact on vegetation composition in the Alps. Aspects that have already been discussed extensively are the expansion of Picea abies (Norway spruce) and Alnus viridis (green alder) and the decline of Abies alba (silver fir) starting in the mid Holocene (e.g. Markgraf, 1970; Welten, 1982; Lang, 1994; Lotter et al., 2006; Rey et al., 2013; Schwörer et al., 2015). At the same time, also Ulmus (elm), Tilia (linden) and Acer (maple) declined, but only a few studies have addressed possible causes. For the southern alpine forelands, Zoller (1960) proposed that increasing precipitation washed out most of the nutrients from the soils being substantial to support the high nutrientdemand of these tree species. In contrast, Welten (1982) suggested that human impact caused the decline of thermophilous tree species in the Valais in the Central Alps. Similarly, Tinner et al. $(1999,2005)$ suggested that excessive anthropogenic fire disturbance caused the collapse of these disturbance-sensitive trees in the lowlands of the Southern Alps. Besides, a popular hypothesis in North-Western Europe is that the Dutch elm disease caused the past as well as the current decline in Ulmus (Perry and Moore, 1987; Molloy and O'Connell, 1987). However, the concurrent mid-to-late Holocene decline of Ulmus, Tilia and Acer in and around the Swiss Alps suggests a common cause. In Great Britain, new studies suggest that increasing anthropogenic 
influence can partly be made responsible for these declines (Parker et al., 2002; Grant et al., 2011). Yet, given the very few available well-dated high-resolution records this question remains open, particularly in regard to mountain vegetation.

Here, we present a local to regional vegetation reconstruction from the new site Lac de Bretaye (1780 m a.s.1.), a small lake in the canton of Vaud, Switzerland. Together with other sites that have been studied recently (Berthel et al., 2012; Rey et al., 2013; Schwörer et al., 2014a, 2015), we provide new insights into Holocene vegetation dynamics on an altitudinal transect in the Northern Swiss Alps. We use a multi-proxy approach, comprising pollen, plant macrofossil, and charcoal analysis as well as direct and indirect gradient analysis to gain a better understanding of vegetation responses and drivers on a local to regional scale (Birks and Birks, 2006). Due to its location in the subalpine belt and its vicinity to other study sites, Lac de Bretaye is very well suited for assessing timberline dynamics. Special attention is paid to the transition from the Neolithic to the Bronze Age with a short high-resolution sequence to assess the impact of human land use on vegetation dynamics and composition (Willis and Birks, 2006). In this study we address the following questions:

(1) What was the timing and speed of afforestation after the Younger Dryas cold period at Lac de Bretaye?

(2) What caused the decline of Ulmus, Tilia and Acer in the mid to late Holocene?

(3) How did climate and human impacts affect biodiversity?

Study site

Lac de Bretaye is a small subalpine lake in the canton of Vaud, Switzerland $\left(46^{\circ} 19^{\prime} 34.42^{\prime \prime N}, 7^{\circ} 4^{\prime} 19.52^{\prime \prime E}\right)$ at an altitude of $1780 \mathrm{~m}$ a.s.l. (Figure 1). It has a surface area of 4 ha, one minor inflow and no surface outflow. The lake's maximum water 
depth is $9 \mathrm{~m}$. The lake is located in a cirque with mountain ridges on three sides and Le Chamossaire (2112 m a.s.l.) as its highest peak. Geologically, the area around Lac de Bretaye consists mainly of limestone and belongs to the Niesen-Nappe, which is part of the Penninic domain of the Alps (Geologischer Atlas der Schweiz, 1962). Today's annual precipitation is $1748 \mathrm{~mm}$ and mean annual temperature is $3.4^{\circ} \mathrm{C}$. January and July mark the coldest and warmest month with temperatures of $-5.3^{\circ} \mathrm{C}$ and $12.6^{\circ} \mathrm{C}$, respectively (extrapolation between the meteorological stations Aigle and Châteaud'Oex in the norm period 1981-2010, MeteoSchweiz, 2005).

The study site is located in the subalpine vegetation belt. Picea abies is the dominating tree species and can be found in patches around the lake and on the surrounding mountain ridges up to c. $2100 \mathrm{~m}$ a.s.l., forming the local treeline in the area c. $300 \mathrm{~m}$ above the site. Treeline is defined as the uppermost limit of individual trees or tree groups $>2 \mathrm{~m}$, while timberline is the uppermost limit of closed forest growth (Körner, 2003; Tinner and Theurillat, 2003). The present timberline is strongly influenced by human impact and is located right below the lake at around $1750 \mathrm{~m}$ a.s.l. The lake is surrounded by subalpine and alpine meadows on three sides, which are used as pastures. The steep slope at the south-eastern side of the lake is mainly covered by Alnus viridis. Some other shrubs, such as Juniperus communis and Rhododendron hirsutum and single trees of Larix decidua, Pinus cembra and Acer pseudoplatanus are present as well.

\section{Methods}

Coring and radiocarbon dating

Comment [L5]: Subheading A

In September 2012 two sediment cores were taken from the lake using a modified Streif-Livingston piston corer with a diameter of $5 \mathrm{~cm}$ (Merkt and Streif, 1970). The two cores (BRE A and BRE B) were taken half a meter apart close to the deepest point 
of the lake at $9 \mathrm{~m}$ water depth. Based on their lithostratigraphy, the two cores were combined to one master core with a total length of $9.50 \mathrm{~m}$. Additionally, a surface core of the upper $40 \mathrm{~cm}$ was taken in October 2012.

The age-depth model used for the analyses is based on 10 radiocarbon dates from terrestrial plant remains (Table 1). The age of the bottom depth was estimated to be 11750 cal. BP based on the biostratigraphical comparison of its pollen assemblage with radiocarbon-dated diagrams from the region (Welten, 1982). The radiocarbon dates were measured with Accelerated Mass Spectrometry (AMS) at the Poznań Radiocarbon Laboratory, Poland. The uncalibrated dates $\left({ }^{14} \mathrm{C}\right.$ ages $)$ were transformed into calibrated years before present (cal. BP) and then used to construct an age-depth model with linear interpolation between the weighted means of the radiocarbon dates and a $2 \sigma$-confidence range. This was done with the program clam 2.2 (Blaauw, 2010), which uses the IntCal13 calibration curve (Reimer et al., 2013) and Monte-Carlo sampling with 1000 iterations (Figure 2).

Pollen, charcoal and loss on ignition analysis

For pollen and microscopic charcoal analyses 75 subsamples of $1 \mathrm{~cm}^{3}$ were taken over the entire core. Material was sub-sampled every 8-16 cm from 560-656 cm and 704-936 $\mathrm{cm}$. From 660-700 cm, subsamples were taken every $2 \mathrm{~cm}$ (high-resolution part) and from $80-560 \mathrm{~cm}$ in different intervals spanning from 16 to $40 \mathrm{~cm}$. Additionally, 5 subsamples were taken from the surface core every $8 \mathrm{~cm}$.

Treatment for pollen analysis followed standard procedures with $\mathrm{HCl}, \mathrm{KOH}, \mathrm{HF}$, acetolysis (Moore et al., 1991) and mounting in glycerine. In order to infer pollen and charcoal concentrations (pollen grains $\mathrm{cm}^{-3}$, charcoal particles $\mathrm{cm}^{-3}$ ) and influx (pollen grains $\mathrm{cm}^{-2} \mathrm{yr}^{-1}$, charcoal particles $\mathrm{cm}^{-2} \mathrm{yr}^{-1}$ ), a known number of Lycopodium spores was added to the samples before chemical treatment (Stockmarr, 1971). Pollen and spore types were identified under the light microscope at 400x to 1000x magnification 
using the reference collection of the Institute of Plant Sciences of the University of Bern as well as pollen keys and photo atlases (Moore et al., 1991; Reille, 1992; Beug, 2004). | 400 pollen grains_per slide_excluding pollen of water plants and spores - were counted and 137 pollen types were identified in total. Stomata were identified following Trautmann (1953). Microscopic charcoal $(>10 \mu \mathrm{m})$ was counted on the pollen slides following Tinner and $\mathrm{Hu}$ (2003) and Finsinger and Tinner (2005). The sum for calculation of pollen percentages includes tree, shrubs and upland herbs, whereas spores and pollen of aquatic plants are excluded. For the pollen diagram, the method of optimal sum of squares partitioning (Birks and Gordon, 1985) was applied to detect local pollen assemblage zones (LPAZ) using the program ZONE 1.2 (Juggins, 1991). Subsequently, statistically significant zones were inferred by using the program BSTICK (Bennett, 1996). Subsamples for loss on ignition analysis were taken from the same depths as for the pollen and charcoal analysis and were treated following Heiri et al. (2001).

\section{Plant macrofossil analysis}

Subsamples of $2 \mathrm{~cm}$ thickness and a volume ranging from 12 to $20 \mathrm{~cm}^{3}$ were taken throughout the core. Special emphasis was given to the time of afforestation, where continuous subsamples from $792-822 \mathrm{~cm}$ depth were taken. The subsamples were sieved with a mesh size of $200 \mu \mathrm{m}$, separating macrofossils from fine-grained sediment. The macrofossils were then identified using the reference collection of the Institute of Plant Sciences of the University of Bern and macrofossil keys (e.g. Schoch et al., 1988). Areas (including charcoal) were estimated using millimeter paper placed under the petri dish. In total, 42 samples were counted. Macrofossil concentrations were calculated per $14 \mathrm{~cm}^{3}$ standard volume. The LPAZ inferred from the pollen diagram were used for the macrofossil diagram for reasons of consistency. 
Ordination analysis. Ordination analyses were used to identify environmental gradients in the whole data set as well as in the high-resolution sequence from $660-700 \mathrm{~cm}$ (c. 4600-3840 cal. BP). The untransformed pollen percentage data were analysed using detrended correspondence analysis (DCA). With gradient lengths of 2.7 for the standard data set and 1.2 for the high-resolution part, DCA and principal component analysis (PCA) were selected as the methods of choice, respectively (Birks and Gordon, 1985; ter Braak and Prentice, 1988). Redundancy analysis (hRDA) was applied to the highresolution data with microscopic charcoal influxes as a proxy for fire as explanatory factor (Colombaroli et al., 2009). The program CANOCO 4.5 (ter Braak and Šmilauer, 2002) was used for all the ordination analyses.

Biodiversity. In order to estimate paleo-biodiversity, palynological richness (PRI) was used as a proxy for both evenness and species richness and PIE (probability of interspecific encounter; Hurlbert, 1971) for pollen evenness. For that purpose, rarefaction calculations were applied using the lowest pollen count of 356 at $192 \mathrm{~cm}$ depth as reference (Birks and Line, 1992). Calculations were done with the program $\mathrm{R}$ statistics (R Development Core Team, 2011). For reasons of comparison, the sample scores of the first DCA axis were plotted, as well.

Results

Comment [L12]: Subheading A

\section{Lithology, chronology and loss on ignition} sediments eore-consists of silty gyttja $(950-835 \mathrm{~cm} ; 11750-10400 \mathrm{cal}$. BP) with fine layers of sand and clay (Figure 3). Between 835 and $830 \mathrm{~cm}$ the lithology changes to gyttja $(830-0 \mathrm{~cm})$. Minor changes in colour are visible at $650 \mathrm{~cm}$ (black to dark brown) 
and $550 \mathrm{~cm}$ (dark brown to brown). Two layers of silty gyttja at $535-530 \mathrm{~cm}$ and 500 $495 \mathrm{~cm}$ may be attributed to erosion events. Fine taminations-layers are best pronounced in the top $150 \mathrm{~cm}$.

The age-depth model depicts a high sedimentation rate in the bottom part of the sediment (950-817 cm; 11750-10250 cal. BP; Figure 2) while from 10250-3900 cal. BP $(817-673 \mathrm{~cm})$ the sedimentation rate is very low and more or less constant $(\mathrm{c} .0 .02 \mathrm{~cm}$ $\mathrm{yr}^{-1}$ on average). In the uppermost $673 \mathrm{~cm}$ (from $3900 \mathrm{cal}$. BP onwards), the

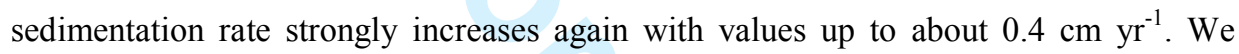
excluded one radiocarbon date from the age-depth model, as it appears to be too young when following the biostratigraphy and the other data. This date, found in a slightly disturbed part of the core might be a contamination artefact, e.g. from material transported downwards during coring.

The loss on ignition analysis shows that the organic content of the sediment remains rather low $(<10 \%$ ) from the bottom to $830 \mathrm{~cm}$ (Figure 2). From $830-720 \mathrm{~cm}$, the values are as high as $60 \%$. In the upper $720 \mathrm{~cm}(5050-0 \mathrm{cal}$. BP), values strongly vary between 36 and $78 \%$. Values for carbonates (loss on ignition at $950^{\circ} \mathrm{C}$ ) stay low throughout the core $(2-5 \%)$. Hence, the residues of the loss on ignition at $550^{\circ} \mathrm{C}$ can be interpreted almost exclusively as silicates. In total, five statistically significant LPAZ are identified (BRE 1-5; Figures 3-5). Furthermore, one additional, non-significant zone boundary has been used to differentiate the youngest LPAZ in two subzones (BRE-5a and $b$ ).

BRE-1: 11750-10350 cal. BP. In the oldest LPAZ, Pinus cembra and Pinus sylvestrisComment [L16]: Sub-subsubheading C type pollen are the dominating pollen taxa, making up about $80 \%$ of the total pollen sum (Figure 3) but Pinus stomata are lacking. Furthermore, mainly pollen of Poaceae 
and Artemisia is present. Pollen of thermophilous species such as Corylus avellana or Fraxinus excelsior is occasionally present. Only in the lowermost sample non-arboreal pollen (NAP) is equally abundant as arboreal pollen (50.8\% and 49.2\%, respectively). Microscopic charcoal concentration and influx are high compared to the following zones. Macrofossils are absent in the lowest part of the core except for two findings of bud scales of Pinus (presumably Pinus cembra) around $11450 \mathrm{cal}$. BP and $10850 \mathrm{cal}$. BP (Figure 4). Towards the end of this zone, at around $10400 \mathrm{cal}$. BP, bud scales of Larix decidua and Pinus, a first needle of P. cembra and remains of dicotyledonous leaves are present. Additionally, macroscopic charcoal is present in very small amounts at the end of the zone.

BRE-2: 10350-6300 cal. BP. The first appearance of pollen of additional thermophilous taxa, like Tilia, Acer, Ulmus, Alnus glutinosa-type and Quercus marks the beginning of the second LPAZ. At the same time, Larix decidua pollen appears for the first time. Pollen percentages of P. cembra, P. sylvestris-type, Artemisia and Poaceae strongly decrease. Herbaceous taxa play a minor role and make up less than $20 \%$ in total. Considering that this zone spans more than 4000 years, moderate changes are evident, such as a decrease in almost all thermophilous pollen and an increase in P. cembra, Fagus sylvatica and Abies alba pollen around 8200 cal. BP. A few Pinus stomata are present in this zone, the first ones found at 10300 cal. BP. Microscopic charcoal concentration rapidly decreases and charcoal influx is very low. Macrofossil concentration increases, tree-Betula and P. cembra are continuously present at the beginning of this zone and bud scales and needles of Larix decidua are found. Dicotyledonous leaf fragments increase, too and are accompanied by bud scales and fruits of Salix. A twig of Alnus and a bud scale of Ulmus occur at 8800 cal. BP and 8350 cal. BP, respectively. Macroscopic charcoal occurs only sporadically and in low concentration. 
BRE-3: 6300-4600 cal. BP. Abies alba becomes the dominant pollen type with a Comment [L19]: Sub-subsubheading C pronounced peak around $5600 \mathrm{cal}$ BP. Picea abies pollen occurs for the first time in this zone. Its percentages slowly increase and show a first peak after the peak in A. alba (5050 cal. BP), but decrease soon afterwards. The strong decline in Ulmus at c. 55005000 cal. BP coincides with a first peak in P. abies, when Plantago alpina reappears for the first time since c. 10000 cal. BP from c. 5050 cal. BP onwards. An increase in Ulmus, Tilia and other thermophilous species is observed at c. 4900 cal. BP when $P$. abies declines after its first peak. No stomata are present in this zone. Microscopic charcoal concentration and influx slightly increase and have a first peak towards the end of the zone (c. 4850 cal. BP). Dicotyledonous leaf fragments increase and many plant remains, such as wood fragments, terrestrial tissue and both coniferous and deciduous periderm are present. Macrofossil remains of Betula, Pinus and L. decidua are found in low numbers. At c. 5800 cal. BP the first macrofossils of Abies alba occur (bud scales and seeds), soon becoming the most frequent conifer findings. Shortly after the first remains of A. alba, a first bud scale of Picea abies is recorded (c. 5550 cal. BP). Macroscopic charcoal influx is higher and more frequent than before, especially towards the end of the zone.

BRE-4: 4600-3800 cal. BP. Picea abies becomes the most abundant pollen type. Fagus sylvatica increases at the beginning to slightly decrease afterwards. Abies alba, in contrast, continmously decreaseshas a continuously decreasing trend. Likewise, Ulmus, Acer and Tilia strongly drop. Declines in Ulmus and Acer are usually simultaneous to increases in P. abies. Alnus viridis pollen increases after having appeared for the first time at c. 7700 cal. BP and the number of herbaceous taxa slightly increases. Additionally, human indicators such as Plantago lanceolata, P. media and Cannabistype occur for the first time. Among stomata, P. abies is dominant, whereas Pinus and 
Larix decidua are sporadic. Microscopic charcoal concentration and influx slightly decrease after an initial peak, but show several smaller peaks. Charcoal concentration and influx have trends that are opposite to Tilia pollen percentages and from the second part of this zone onwards also to Ulmus and Acer percentages. In agreement, macrofossils of P.ieea abies are frequent throughout the zone. Macrofossils of Abies alba are still quite frequent, whereas those of Betula, Pinus and L. decidua (needles) are rare. The only identifiable macrofossils of thermophilous deciduous woody plants in this zone are bud scales and fruits of Acer. Values for macrofossil-macroscopic charcoal are high and frequent, comparable to the previous zone.

BRE-5a: 3800-2150 cal. BP. This subzone is characterised by a massive increase of Alnus viridis pollen and a continuing decline of Abies alba. Ulmus and Tilia disappear completely in the first half (around 2800 cal. BP). Besides, more herb pollen occurs and the percentages of all herbaceous taxa slightly increase. Human indicators such as Plantago alpina, P. lanceolata, P. media, Ranunculus acris-type and Rumex acetosa become more and more abundant. The previously sparse coprophilous fungus Sporormiella is now constantly present. Most stomata encountered belong to $P$. abies, a few to Pinus or L. decidua. Pronounced peaks of microscopic charcoal concentration and influx occur at the beginning and end of the sub-zone. Charcoal influx is clearly higher than in the zones before. Macrofossils of Betula, Pinus and L. decidua are occasionally present and macrofossils of Abies alba slightly decrease. Macrofossils of Picea $P$. abies are quite frequent. Besides a large number of deciduous leaf fragments and many other unidentifiable plant remains, the record shows bud scales of Acer and seeds of Alnus at c. 2750 cal. BP. Macroscopic charcoal distinctly peaks (Holocene maximum) around $2450 \mathrm{cal}$. BP. 
BRE-5b: 2150- $-60 \mathrm{cal}$. BP. At the beginning of this sub-zone, extreme peaks in microscopic charcoal concentration and influx at $2050 \mathrm{cal}$. BP are accompanied by a strong decrease in tree and shrub pollen and a strong increase in herb pollen to $50 \%$ of the pollen sum. Together with pollen indicative of land use (e.g. Plantago alpina, $P$. lanceolata, P. media, Ranunculus acris-type, Rumex acetosella) Sporormiella strongly increases at the same time and there is a pronounced increase in Poaceae, Cyperaceae, Ranunculaceae, Rumex and Plantago. Picea abies dominates among tree pollen and increases towards the top. Alnus viridis pollen stays rather high (5-10\%). Juglans regia pollen is continuously present from 2050 cal. BP onwards and Castanea sativa pollen is encountered in higher numbers than before. Only Picea abies stomata are present and macrofossil remains are very rare; the only identifiable remains are Betula (bud scales) and P. abies (bud scales and needles), and both deciduous and coniferous periderm occurs. The concentration of macroscopic charcoal is low.

Ordination and diversity proxies

The clustering of samples and species in a scatterplot (Figure 6) closely follows the six local pollen assemblage zones (LPAZ). Axis 1 explains $29.4 \%$ of the variance and describes the millennial-long vegetation succession from Pinus sylvestris-type and Pinus cembra (BRE-1) over thermophilous tree species such as Corylus avellana, Ulmus and Tilia (BRE-2) to Abies alba (BRE-3), followed by Picea abies (BRE-4), Alnus viridis, Castanea sativa and Juglans regia. The second axis explains $13.3 \%$ of the variance and shows a gradient from forest (BRE-1-4) to a more anthropogenic landscape including herbs indicative for human disturbance like Plantago lanceolata, among others (BRE-5a and b) and tree species favoured by humans (Castanea sativa, Juglans regia).

In the high-resolution sequence (Figure 7; 4600-3850 cal. BP), the first axis of the principal component analysis (PCA) explains $51.5 \%$ of the variance with Picea abies, 
Quercus, Plantago lanceolata, Urtica dioica, Alnus viridis on the left side and Ulmus, Acer, Pinus cembra and, less pronounced, Tilia and Abies alba on the right. The second axis explains $21.4 \%$ of the variance and depicts a prominent distinction between herb and shrub pollen on the bottom and Abies alba together with Tilia on the top.

The microscopic charcoal influx as a proxy for fire explains $13.5 \%$ of the variance in the high-resolution sequence (Figure 7) and is positively correlated with herb pollen such as Rumex obtusifolius-type as well as Alnus viridis and Alnus glutinosa-type (pvalue < 0.05). In contrast, Fagus sylvatica, Abies alba and Tilia are negatively correlated with microscopic charcoal while other taxa are not significantly correlated. The second, unconstrained axis accounts for $50.4 \%$ of the variance. It contrasts Ulmus, Acer, but also Fraxinus excelsior and Corylus avellana on the one hand and Picea abies and Quercus on the other (Figure 7).

Both pollen richness and pollen evenness are very low at the beginning, followed by a steep, sudden increase in both indices at ca. 10300 cal. BP (Figure 8). From then on, pollen evenness steadily rises until around $5000 \mathrm{cal}$. BP, while pollen richness stays more or less constant. Afterwards, the values of pollen evenness slightly decrease but stay high, while pollen richness increases with a pronounced shift to high values of ca. 40-50 taxa per sample at ca. $2000 \mathrm{cal}$. BP.

The chronology of the biostratigraphy_-which-is ehronelogically-well-constrained by many radiocarbon-dated records from the region (e.g. Welten, 1982; Rey et al., 2013) suggestings that the lake started to collect sediment at the very end of the Younger Dryas cold phase when temperatures were rising and glaciers receded (Schwander et al., 
2000). From $11750-10350$ cal. BP, loss on ignition values at $550^{\circ} \mathrm{C}$ show low organic matter input (Figures 2, 9e; Heiri et al., 2001). Our combined pollen and macrofossil evidence shows that during this time, vegetation around the lake was rather sparse and consisted of open alpine meadows with Poaceae and Artemisia. The complete lack of herb macrofossils suggests that the meadows were-very open (Figure 4; Tinner and Theurillat, 2003). However, earliest macrofossils of Pinus (bud scales at 11450 and 10850 cal. BP; Figure 4) indicate that trees were present in the area around the lake already at the onset of the early Holocene, though in low abundances, which is in agreement with the pollen evidence (high pollen percentages of Pinus cembra). Increasing abundances of tree macrofossils from $10300 \mathrm{cal}$. BP onwards suggest that timberline reached the site at that time (Figure 4). The establishment of forests in the catchment likely stabilized the soils and limited erosion input into the lake. This is suggested by the drastic decrease in the sedimentation rate and the increasing values of organic matter in the sediment (Figure 2).

North of the Alps, timberline was located at around $1000 \mathrm{~m}$ a.s.l. during the Younger Dryas (Welten, 1952, 1982; Heiri et al., 2014). The rise in temperature of c. $1.5-3^{\circ} \mathrm{C}$ at the Younger Dryas - Holocene transition (Lotter et al., 2000; Heiri et al., 2003b) caused a rapid upward movement of timberline to the elevation of Lauenensee (1381 m a.s.l.) by 11600 cal. BP (Rey et al., 2013). Despite the presence of single trees around Lac de Bretaye (1780 m a.s.1.) at c. $11450 \mathrm{cal}$. BP, our results show that afforestation around the lake took place about 1100 years later (at $10300 \mathrm{cal}$. BP). Hence, timberline needed more than 1000 years to overcome the altitudinal distance of about $400 \mathrm{~m}$ between Lauenensee and Lac de Bretaye. This afforestation delay may be partly explained by a strong decrease in summer temperatures during the Preboreal Oscillation (11350-11100 cal. BP) and the subsequent Central European cold phase 1 (CE-1, 10950-10300 cal. BP; Haas et al., 1998; Schwander et al., 2000; Tinner and Kaltenrieder, 2005). Other explanations for this delay might be a higher seasonality due to orbital forcing or the 
presence of large ice sheets in Northern Europe that, through cold air spells, may have affected the treeline vegetation in the Northern Alps (Schwörer et al., 2014a). After its establishment around Lac de Bretaye around 10300 cal. BP, timberline then needed about 500 years to reach the elevations of Iffigsee $(2065 \mathrm{~m}$ a.s.1.) where it established around 9800 cal. BP (Schwörer et al., 2014a). These results indicate that the delayed early-Holocene afforestation at higher altitudes in the Northern Swiss Alps was a regional trend rather than a local signal. Afforestation was earlier in the Central Alps. For instance the timing of vegetational change at Lac de Bretaye is comparable with that at Gouillé Rion in the Valais, though there, open Larix decidua forests established at 11350 cal. BP and dark P. cembra stands at 10200 cal. BP (Tinner and Kaltenrieder, 2005). There, these vegetational shifts were explained by climatic change involving increasing temperatures and moisture availability, respectively.

Early Holocene timberline forests at Lac de Bretaye were mainly formed by Betula and Pinus cembra. This vegetation type occurred also at other sites in the Northern Alps such as Bachalpsee, Sägistalsee and Hinterburgseeli (Figure 4; Wick et al., 2003; Heiri et al., 2003a; Lotter et al., 2006). Larix decidua was only sparsely present (Figures 3, 4) and not as dominant as at Iffigsee, perhaps due to slightly more oceanic conditions at Lac de Bretaye (Schwörer et al., 2014a). Swiss stone pine (Pinus cembra) is a shade tolerant, late successional species and outcompetes tareh $(L$. decidua $)$ on deeper soils and/or high moisture availability (Ellenberg and Leuschner, 2010), conditions presumably found at Lac de Bretaye. Despite their former importance, today's Swisf stone pineP. cembra forests are extremely rare in the Northern Alps and usually restricted to unfavourable and remote rocky habitats (Landolt, 2003).

High-altitudinal thermophilous forests and the expansion of mixed Abies-forests 100005500 cal. BP 
At the time of afforestation at Lac de Bretaye (10300 cal. BP), many thermophilous deciduous trees and shrubs such as Corylus avellana (hazel), Acer-(maple), Ulmus (elm), Tilia-(linden), Fraxinus excelsior (ash), Alnus glutinosa and Alnus incana (black and grey alder) and Quercus (oak) expanded in the lowlands, causing the pollen percentages of Pinus to decline (Figures 3, 6, 9a). The expansion of these species was probably enabled by maximum summer insolation at around 10000 cal. BP (Figure 9i; Laskar et al., 2004; Wanner et al., 2008), leading to summer temperatures about $1-2^{\circ} \mathrm{C}$ higher than today (Figure 9h; Heiri et al., 2003b; Renssen et al., 2012). This triggered timberline positions as high as $2250 \mathrm{~m}$ a.s.1., $300 \mathrm{~m}$ higher than in the study region north of the Alps at present (Lotter et al., 2006; Berthel et al., 2012). High summer temperatures during this Holocene Thermal Maximum (HTM) probably also allowed thermophilous species to reach the surroundings of Lac de Bretaye. Today, the altitudinal limit of Ulmus and Alnus glutinosa is around $1400 \mathrm{~m}$ a.s.l and that of Acer at 1800 m a.s.l. (Welten, 1952; Lauber et al., 2012). Macrofossil findings of Alnus (8800 cal. BP) and Ulmus (8350 cal. BP) testify to the local presence of these species around the study site (Figure 4). Additionally, the pollen influx of Tilia and Ulmus (Figure 9a) is compared with influx values at Soppensee, a lowland site where the species' local presence was inferred from macrofossils (Lotter et al., 1999). When - according to the macrofossil evidence - Ulmus is present at Soppensee, influx values are between 2500 and 5000 pollen grains cm-2 yr-1, while they reach a peak of c. 2700 at Lac de Bretaye, again pointing to the local presence of the tree at our study site. At Soppensee, on the basis of macrofossils Tilia dominated forests can be inferred for influx values $>$ c. 300 (Lotter et al., 1999). A maximum influx of around 350 at Lac de Bretaye suggests that Tilia was growing at our high-elevation site, possibly also in considerable abundance. Given that cold-adapted Pinus cembra, Betula and Larix decidua are also documented as macrofossils we infer the presence of unique mixed boreo-nemoral forests for the period 10300-5500 cal. BP (Felde et al., 2014). Today, such forests do not exist in the 
Alps, and their closest analogues are located in Scandinavia or Central and Eastern Siberia where under continental conditions (high summer, low winter temperatures) Pinus and Larix can form forests together with Ulmus and Tilia (Walter, 1974).

At around 8200 cal. BP, temperatures in the Northern Swiss Alps and Central Europe dropped by about $2^{\circ} \mathrm{C}$ (Figure 9h; von Grafenstein et al., 1999; Heiri et al., 2003b). Vegetation reacted very quickly to this cooling, as a lowering of timberline as well as open forest conditions can be inferred from pollen and macrofossil records (Figures 3, 4; e.g. Wick and Tinner, 1997; Heiri et al., 2003a; Tinner and Kaltenrieder, 2005; Valsecchi et al., 2010) and from vegetation models (Heiri et al., 2006). At Lac de Bretaye, pollen of thermophilous tree species (especially Ulmus) declined and more | cold-adapted tree species such as Swiss stone pine $(P$. cembra) and herbs increased (Figure 3). However, vegetation recovered after the return to warmer conditions (Figures 3, 9h). A consequence of this cooling event was a shift to more oceanic climate conditions with milder winters (Figure 9i; Laskar et al., 2004) and higher precipitation rates (Figure 9k; Magny, 2004; Magny et al., 2011), probably due to a change in atmospheric circulation patterns over the North Atlantic and Europe (Seppä and Birks, 2001). These changes allowed for the expansion of mesophilous species such as Fagus | sylvatica (beech)-and Abies alba (silver fir; Figures 3, 6; e.g. Tinner and Lotter, 2001, 2006). Our pollen record suggests that $A$. alba expanded at or slightly below the site at c. 8500-8000 cal. BP, while macrofossil remains point to its local presence at least from 5800 cal. BP onwards (Figure 4). At that time, Tilia and Ulmus still had high pollen abundances. Drastic declines of these species occurred only after 5500 cal. BP. Acer, Ulmus and Tilia persisted over c. 1500 years until their local extinction at c. 3500 cal. BP (Figures 3, 9a). Abies alba co-varied with Ulmus, Tilia and Acer (Figure 3), as also observed at other sites in the Northern, Central and Southern Alps (e.g. Zoller, 
1960; Welten et al., 1982; Tinner et al., 1999; Heiri et al., 2003a; Rey et al., 2013), though its local extirpation at Lac de Bretaye occurred only during the past 200 years $(<1 \%)$. The most obvious opposing trend during that time is the expansion of Picea abies (Figures 3, 6, 7, 9a, b). Many studies have dealt with the late establishment of Picea abies and suggested different causes, such as a migrational lag, climate conditions or soil development (Lang, 1994; Ravazzi, 2002; Lotter et al., 2006; Henne et al., 2011). Growing evidence suggests that the mass expansion of Picea abies was triggered by increasing human impact in the Neolithic (Markgraf, 1970; Rey et al., 2013; Schwörer et al., 2015). This led to a decline in Abies alba and allowed Picea abies to take over its ecological niche at high altitudes (Schwörer et al., 2015).

Our new data suggest that the human-induced expansion of Picea abies was connected to the decline of Tilia, Ulmus and Acer at our high-altitudinal site. The alternating declines and increases of Picea abies and the other trees show a competition between these species (Figures 3, 5, 6, 7, 9a, b). Data from Scandinavia suggest that Tilia is strongly disadvantaged by Picea abies (Seppä et al., 2009). The PCA analysis reveals that Ulmus, Acer and, to a minor degree, Tilia and Abies alba were antagonists of Picea abies during the period from 4600-3850 cal. BP (Figure 7). During the same time period, Tilia, Abies alba, Acer and - less pronounced - Ulmus were clearly negatively correlated with human impact indicators (Figure 7), suggesting that increasing land use contributed to exclude these taxa from the forests. Welten (1982) was the first to recognize this link in the Central Alps. However, until now quantitative evidence was available only from the Southern Alps (Tinner et al., 1999), where this impoverishment process was mainly driven by excessive human fire disturbance.

The ecological role of fire

Comment [L32]: Subsubheading B cal. BP indicate a rather high regional fire activity (Figures 3, 9c; e.g. Tinner et al., 
2008). The absence of macroscopic charcoal suggests that forest fires did not occur locally, perhaps due to open vegetation conditions (Figure 4). Only after $10300 \mathrm{cal}$. BP, macroscopic charcoal findings point to local fires around Lac de Bretaye (Figure 4), probably in response to increased forest cover around the site and warmer summer conditions (summer insolation maximum, Heiri et al., 2004). Yet, their impact on vegetation was negligible. Regional fire activity probably decreased to a minimum (Figures 3, 4) for the Holocene during 10000-5500 cal. BP, after summer insolation had culminated.

Fire incidences augmented only after 5500 cal. BP (Figures 3-5, 9c, d) with increasing anthropogenic activity as suggested by the appearance and expansion of taxa such as Plantago lanceolata, heliophilous P. alpina, Rumex acetosa, Ranunculus acris and Cannabis sativa and dung-spores of Sporormiella. The positive correlation of fire with important human-indicator species confirms that fires at and around the site were of anthropogenic origin (Figure 7). Increasing sedimentation rates and the high variability in the loss on ignition values (Figure 2) may have resulted from higher erosion in response to land use activities such as early human deforestation (increase of NAP at 5500-5000 cal. BP, Figure 3).

Abies alba is very sensitive to fire (e.g. Tinner et al., 2000) and a high fire frequency may prevent A.bies alba from recovering after disturbance. Similarly, Tilia, Acer and Ulmus are disadvantaged by fire (Delarze et al., 1992; Tinner et al., 2000). These sensitivities are mirrored in the hRDA plot (Figure 7), where microscopic charcoal influx is negatively correlated with Abies alba and Tilia, while Ulmus and Acer are only slightly negatively affected. An explanation for this weak correlation is that the time period of the hRDA (4600-3850 cal. BP, 750 years) might be too short to detect a more drastic impact on Ulmus and Acer. A close look in the pollen diagram exposes a shift in the relation of microscopic charcoal and Ulmus: in the beginning of the high-resolution sequence (c. 4600 cal. BP), Ulmus is slightly positively correlated with microscopic 
charcoal. A shift towards a negative correlation is visible at around $4200 \mathrm{cal}$. BP. This may indicate that Ulmus could cope with fire events at the beginning but was not able to permanently stand the increase in regional fire activity (Figures 5, 9a, c). Taken together, we assume that the more intense (i.e. forest) fires after $3800 \mathrm{cal}$. BP led to the local extinction of Ulmus and Tilia, as they could not recover from this disturbance. The low sensitivity of Acer to fire in the hRDA plot might be because Acer could cope slightly better with fire disturbances. Indeed, in contrast to Tilia and Ulmus, this taxon drastically declined but was not completely eliminated during the late Holocene.

Overall, fire incidents had a moderate impact on vegetation during the period 46003850 cal. BP, with charcoal values explaining $13.5 \%$ of the variance in the data (Figure 7). For comparison, charcoal may explain up to $30 \%$ in fire-prone regions like the Mediterranean (e.g. Colombaroli et al., 2009).

\section{Underlying climatic changes}

In the late Holocene, summer insolation continued to decrease (Figure 9i) and climate gradually shifted to cooler conditions around 4000-3700 cal. BP (Figure 9h; Heiri et al., 2003b). Multi-centennial cold-humid phases occurred at c. 5350-4900 cal. BP and 3800-3400 cal. BP (CE-6 and CE-7, Figure 91; Haas et al., 1998). Tilia and Ulmus could have directly suffered from a colder and moister climate, since both species are rather sensitive to cold and wet conditions (Ellenberg and Leuschner, 2010). Acer, being slightly more adapted to cooler conditions, was perhaps less affected (Ellenberg and Leuschner, 2010). Taking into account that these climatic changes were responsible for a lowering of timberline of about $100 \mathrm{~m}$, the boreo-nemoral forests could have been affected likewise and been shifted downwards. However, the total loss of these species in the area cannot be explained by these climatic changes only. Furthermore, pollen of Quercus - a fire and disturbance-resistant thermophilous genus, as well - follows the course of $P$. abies (Figures 3,6,7), contradicting a triggering by climate. We thus 
assume that the final decline in Tilia and Ulmus was primarily caused by human impact and that changing climatic conditions might have exacerbated this effect.

Human impact from the Bronze Age until today Increasing abundances of the dung-spore Sporormiella, the cultural indicators Plantago lanceolata (for lower elevations), P. alpina and other herbs (e.g. Cichorioideae, Rumex acetosa, Ranunculus acris, Cannabis sativa) suggest that grazing pressure increased dramatically during the Bronze Age, at least since 3800 cal. BP to remain high until today (Figures 3, 9d, Tinner et al., 1996). Similar strong increases of land use activity are documented at other sites close by (Heiri et al., 2003a; Wick et al., 2003; Rey et al., 2013). The forest was heavily disrupted (AP $>80 \%$ to $<40 \%$ ) and Alnus viridis expanded in the area, which is in agreement with findings at many other sites in the Alps (Figure 3; Welten, 1982; Tinner et al., 1996; Gobet et al., 2003; David, 2010). These severe impacts on the environment were made possible due to new techniques and innovations in the Bronze and Iron Age (e.g. Tinner et al., 2003; Tinner et al., 2005).

Both microscopic and macroscopic charcoal findings suggest that human-induced fire frequency (and possibly severity) increased during the Bronze Age after c. 3800 cal. BP to remain high for the next 2500 years (Figures 3, 4, 9c) until the Late Iron Age. Macroscopic charcoal suggests a possible forest fire around 2450 cal. BP (Figure 4), while according to microscopic charcoal suggest that regional fire frequency reached its Holocene peak at around $2100 \mathrm{cal}$. BP (Figure 3, 9c). Despite the age difference, both fire events occurred during the Iron Age. Maxima of fire activity during the Iron Age are typical for the region and may indicate that the Celtic Iron Age cultures had developed a fire-based agriculture type, which ceased during and after the Roman Time (Tinner et al., 2005). Due to this high use of fire, timberline was lowered in the Alps (Haas et al., 1998; Heiri et al., 2003a; Tinner and Theurillat, 2003; Heiri et al., 2006). 
Around Lac de Bretaye, fire incidence probably caused timberline to descend below the altitude of the lake as indicated by joint charcoal, macrofossil, stomata and pollen evidence (Figures 3, 4). Erosion further increased as indicated by higher sedimentation rates (Figures 2, 9e). During Roman Times new crops were introduced in the lowlands (e.g. continuous curves and high findings of Juglans regia and Castanea sativa, respectively, from c. 2100 cal. BP onwards, Figure 3). In the last 50 years, land use in the Alps declined, causing a re-advance of timberline back to higher elevations (GehrigFasel et al., 2007). This process may have caused the weak expansion of AP in the most recent sample of our pollen sequence (e.g. expansion of Larix decidua).

Climate change and human impact as drivers for biodiversity fairly low from 11750-10300 cal. BP, indicating low species diversity (including richness and evenness) in the area (Figure 8). The jump of palynological evenness and richness at around 10400-10300 cal. BP suggests that plant communities became more diverse when the area around the lake became forested and thermophilous species expanded in the lowlands (Figures 3, 4, 8, 9a). Subsequently, the divergent course of PRI (stable) and PIE (increasing) suggests that vegetation became more even but not necessarily richer (Colombaroli et al., 2013). Highest evenness was reached when Abies alba expanded and reached maximum abundances (c. 6000-4500 cal. BP) together with warm-loving taxa. Increases in PRI (PIE stable) from the onset of the Bronze Age (4300 cal. BP) until the past 2000 years (Figures 3, 8) coincide with the increase in microscopic charcoal and indicators of land use (Figures 9c, d, f), pointing to a decisive role of anthropogenic fire regimes for diversity. Our data show that together with high fire incidence many species which are typical of open meadows and grasslands were promoted (Rumex, Plantago, Humulus, Caryophyllaceae) at the expenses of forest trees (Ulmus, Tilia, Abies alba, Acer) around 4800-5000 cal. BP (BRE 3-4) and 4000 cal. BP 
(BRE 4-3a). Hence, fire may have promoted biodiversity (e.g. Colombaroli et al., 2008), though excessive fire activity (frequency, severity) may have negatively impacted forest arboreal diversity. As previously shown, prehistorical and historical diversity may thus have maximized at intermediate levels of disturbance (e.g. Tinner et al., 1999; Tinner and Ammann, 2005, Colombaroli et al., 2013). Taken together, land use and fire were crucial to reach the contemporary biodiversity. This diversity mainly derived from the creation of a mosaic of different vegetation types with novel, land use-dependent vegetation communities, compensating species losses in the forests (e.g. local extinctions of Ulmus and Tilia). Our data imply that the decline of land use activity that started about 50 years ago may endanger open land richness but be beneficial for forest arboreal diversity in the Alps.

\section{Conclusions}

The analysis of lake sediments from Lac de Bretaye, a small subalpine lake in the Northern Swiss Alps, presents new insights into Holocene vegetation dynamics. Our data suggest that the site was at treeline between 11450 and 10300 cal. BP and that timberline reached the site at around 10300 cal. BP, which is in good agreement with evidence from other high-altitudinal sites in the Northern Alps. If compared to the Central and Southern Alps the delayed afforestation at high altitudinal sites in the Northern Swiss Alps (e.g. Iffigsee, Schwörer et al., 2015) points to climatic disparities across the Alps at the beginning of the Holocene. Combined results from Lauenensee, Lac de Bretaye and Iffigsee show that afforestation needed more than 1000 years to overcome the altitude difference of about $400 \mathrm{~m}$ between elevations of Lauenensee and Lac de Bretaye, presumably due to centennial cold events (Preboreal Oscillation, CE-1, Haas et al., 1998; Tinner and Kaltenrieder, 2005) and another 500 years to reach 
elevations of Iffigsee. From 10300-5500 cal. BP, favourable climatic conditions allowed for thermophilous tree species, such as Ulmus, Tilia and Acer not only to grow in the lowlands but also to reach the high elevations of our study site. Together with Pinus and Betula, they formed distinctive mixed boreo-nemoral forests. After 5500 cal. BP, human impact became the main driver for vegetation composition. As a consequence, Picea abies forests and alpine meadows replaced the species-rich boreo-nemoral forests. However, overall biodiversity (especially in grasslands and open areas) increased.

Global warming will cause unprecedented changes in vegetation composition and distribution (Henne et al., 2011; Schwörer et al., 2014b). Timberline is likely to shift upwards displacing alpine meadows, potentially causing irrecoverable losses of biodiversity. This may be prevented by moderate human land use (e.g. Colombaroli et al., 2010; Schwörer et al., 2015). Our data imply that thermophilous trees (Ulmus, Tilia, Acer, Abies alba) wayill rapidly re-expand into the subalpine belt if land use will further decrease. This process might will be accelerated by global warming which may contributinge to the decline of mesophilous species such as Picea abies in the Alps (Tinner et al., 2013) and facilitatinge the return of thermophilous Ulmus, Tilia and Acer. Further multiproxy high-resolution and modelling studies may helpare needed to

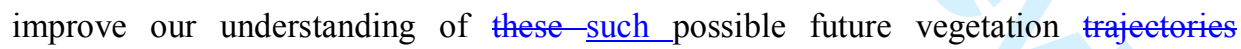

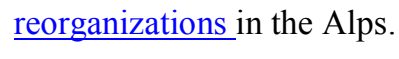

\section{Acknowledgements}

Comment [L37]: Subheading A

We gratefully thank Willi Tanner and Carole Adolf for help during the fieldwork, Florencia Oberli for the laboratory instructions and Pim van der Knaap for valuable | comments and two anonymous reviewers for valuable suggestions on the manuscript. We are grateful to the Dr. Alfred Bretscher Foundation for financial support. 
Ammann B, Birks HJB, Brooks SJ et al. (2000) Quantification of biotic responses to rapid climatic changes around the Younger Dryas - a synthesis. Palaeogeography, Palaeoclimatology, Palaeoecology 159(3-4): 313-347.

Bennett KD (1996) Determination of the Number of Zones in a Biostratigraphical Sequence. New Phytologist 132 (1): 155-170.

Berthel N, Schwörer C, Tinner W (2012) Impact of Holocene climate changes on alpine and treeline vegetation at Sanetsch Pass, Bernese Alps, Switzerland. Review of Palaeobotany and Palynology 174: 91-100.

Beug HJ (2004) Leitfaden der Pollenbestimmung für Mitteleuropa und angrenzende Gebiete. München: F. Pfeil.

Birks HJB, Birks HH (2006) Multi-proxy studies in palaeolimnology. Vegetation History and Archaeobotany 15(4): 235-251.

Birks HJB, Gordon A (1985) Numerical methods in Quaternary pollen analysis. London: Academic Press.

Birks HJB, Line JM (1992) The use of rarefaction analysis for estimating palynological richness from Quaternary pollen-analytical data. The Holocene 2(1): 1-10.

Blaauw M (2010) Methods and code for 'classical' age-modelling of radiocarbon sequences. Quaternary Geochronology 5(5): 512-518.

CH2011 (2011) Swiss climate change scenarios CH2011. Zürich: C2SM, MeteoSwiss, ETH, NCCR Climate, OCCC.

Colombaroli D, Beckmann M, van der Knaap WO et al. (2013) Changes in biodiversity and vegetation composition in the central Swiss Alps during the transition from pristine forest to first farming. Diversity and Distributions 19(2): 157-170.

Colombaroli D, Henne PD, Kaltenrieder P et al. (2010) Species responses to fire, climate and human impact at tree line in the Alps as evidenced by palaeo-environmental records and a dynamic simulation model. Journal of Ecology 98(6): 1346-1357. 
Colombaroli D, Tinner W, van Leeuwen JFN et al. (2009) Response of broadleaved evergreen Mediterranean forest vegetation to fire disturbance during the Holocene: insights from the peri-Adriatic region. Journal of Biogeography 368(2): 314-326.

Colombaroli D, Vanniere B, Emmanuel C et al. (2008) Fire-vegetation interactions during the Mesolithic-Neolithic transition at Lago dell'Accesa, Tuscany, Italy. The Holocene 18(5): 679-692.

David F (2010) Expansion of green alder (Alnus alnobetula [Ehrh] K. Koch) in the northern French Alps: a palaeoecological point of view. Comptes Rendus Biologies 333(5): 424-428.

Delarze R, Caldelari D, Hainard P (1992) Effects of fire on forest dynamics in southern Switzerland. Journal of Vegetation Science 3(1): 55-60.

Ellenberg H, Leuschner C (2010) Vegetation Mitteleuropas mit den Alpen in ökologischer, dynamischer und historischer Sicht. Stuttgart: Ulmer.

Felde VA, Peglar SM, Bjune AE, Grytnes JA, Birks JHB (2014) The relationship between vegetation composition, vegetation zones and modern pollen assemblages in Setesdal, southern Norway. The Holocene 24(8): 985-1001.

Finsinger W, Tinner W (2005) Minimum count sums for charcoal concentration estimates in pollen slides: accuracy and potential errors. The Holocene 15(2): 293-297.

Gehrig-Fasel J, Guisan A, Zimmermann NE (2007) Tree line shifts in the Swiss Alps: climate change or land abandonment? Journal of Vegetation Science 18(4): 571-582.

Geologischer Atlas der Schweiz 1:25000 (1962) Wabern: Bundesamt für Landestopografie swisstopo.

Gobet E, Tinner W, Bigler C et al. (2005) Early-Holocene afforestation processes in the lower subalpine belt of the Central Swiss Alps as inferred from macrofossil and pollen records. The Holocene 15(5): 672-686.

Gobet E, Tinner W, Hochuli PA et al. (2003) Middle to late Holocene vegetation history of the upper Engadine (Swiss Alps): the role of man and fire. Vegetation History and Archaeobotany 12(3): 143-163. 
Grant MJ, Waller MP, Groves JA (2011) The Tilia decline: vegetation change in lowland Britain during the mid and late Holocene. Quaternary Science Reviews 30(3-4): 394-408.

Haas J, Richoz I, Tinner W et al. (1998) Synchronous Holocene climatic oscillations recorded on the Swiss Plateau and at timberline in the Alps. The Holocene 8(3): 301309.

Harsch MA, Hulme PE, McGlone MS et al. (2009) Are treelines advancing? A global meta-analysis of treeline response to climate warming. Ecology Letters 12(10): 10401049 .

Heiri C, Bugmann H, Tinner W et al. (2006) A model-based reconstruction of Holocene treeline dynamics in the Central Swiss Alps. Journal of Ecology 94(1): 206-216.

Heiri O, Lotter AF, Hausmann S et al. (2003b) A chironomid-based Holocene summer air temperature reconstruction from the Swiss Alps. The Holocene 13(4): 477-484.

Heiri O, Lotter AF, Lemcke G (2001) Loss on ignition as a method for estimating organic and carbonate content in sediments: reproducibility and comparability of results. Journal of Paleolimnology 25(1): 101-110.

Heiri O, Tinner W, Lotter AF (2004) Evidence for cooler European summers during periods of changing meltwater flux to the North Atlantic. PNAS 101: 15285

Heiri O, Wick L, van Leeuwen JFN et al. (2003a) Holocene tree immigration and the chironomid fauna of a small Swiss subalpine lake (Hinterburgsee, $1515 \mathrm{~m}$ a.s.1.). Palaeogeography, Palaeoclimatology, Palaeoecology 189(1-2): 35-53.

Heiri O, Brooks SJ, Renssen H et al. (2014) Validation of climate model-inferred regional temperature change for late-glacial Europe. Nature Communications 5 (4914):

Henne PD, Elkin CM, Reineking B et al. (2011) Did soil development limit spruce (Picea abies) expansion in the Central Alps during the Holocene? Testing a palaeobotanical hypothesis with a dynamic landscape model. Journal of Biogeography 38(5): 933-949.

Hoiss B, Gaviria J, Leingärtner A et al. (2013) Combined effects of climate and management on plant diversity and pollination type in alpine grasslands. Diversity and Distributions 19(4): 386-395. 
Hurlbert, S. (1971) The nonconcept of species diversity: a critique and alternative parameters. Ecology 52: 577-586.

IPCC, 2013: Climate Change 2013: The Physical Science Basis. Contribution of Working Group I to the Fifth Assessment Report of the Intergovernmental Panel on Climate Change [Stocker TF, Qin, D, Plattner G-K, Tignor M, Allen SK, Boschung J, Nauels A, Xia Y, Bex V, Midgley PM (eds.)]. Cambridge University Press, Cambridge, United Kingdom and New York, NY, USA, 1535 pp.

IPCC (2014) Climate Change 2014: Impacts, Adaptation and Vulnerability. Part B: Regional Aspects. Contribution of Working Group II to the Fifth Assessment Report of the Intergovernmental Panel on Climate Change [Barros VR, Field CB, Dokken DJ, Mastrandrea MD, Mach KJ, Bilir TE, Chatterjee M, Ebi KL, Estrade YO, Genova RC, Girma B, Kissel ES, Levy AN, MacCracken S, Mastrandrea PR, White LL (eds.)]. Cambridge University Press, Cambridge, United Kingdom and New York, NY, USA, $688 \mathrm{pp}$.

Juggins S (1991) Zone 1.2. Freeware. Available at: http://www.staff.ncl.ac.uk/staff/stephen.juggins/software.htm. (Accessed 10 October 2013).

Körner C (2003) Alpine plant life: Functional plant ecology of high mountain ecosystems, 2nd edn. Berlin: Springer.

Körner C (2012) Alpine treelines. Basel: Springer.

Landolt E (2003) Unsere Alpenflora, 7th edn. Bern: SAC-Verlag.

Lang G (1994) Quartäre Vegetationsgeschichte Europas. Jena: Fischer.

Laskar J, Robutel P, Joutel F et al. (2004) A long-term numerical solution for the insolation quantities of the Earth. Astronomy and Astrophysics, 428(1): 261-285.

Lauber K, Wagner G, Gygax A (2012) Flora Helvetica. Bern: Haupt.

Leonelli G, Pelfini M, Di Morra Cella U et al. (2011) Climate Warming and the Recent Treeline Shift in the European Alps: the Role of Geomorphological Factors in HighAltitude Sites. Ambio 40(3): 264-273. 
Lotter AF (1999) Late-glacial and Holocene vegetation history and dynamics as shown by pollen and plant macrofossil analyses in annually laminated sediments from

Soppensee, central Switzerland. Vegetation History and Archaeobotany 8(3): 165-184.

Lotter AF, Birks HJB, Eicher U et al. (2000) Younger Dryas and Allerød summer temperatures at Gerzensee (Switzerland) inferred from fossil pollen and cladoceran assemblages. Palaeogeography, Palaeoclimatology, Palaeoecology 159 (3-4): 349-361.

Lotter AF, Heiri O, Hofmann W et al. (2006) Holocene timber-line dynamics at Bachalpsee, a lake at $2265 \mathrm{~m}$ a.s.l. in the northern Swiss Alps. Vegetation History and Archaeobotany 15(4): 295-307.

MacDonald D, Crabtree JR, Wiesinger G et al. (2000) Agricultural abandonment in mountain areas of Europe: Environmental consequences and policy response. Journal of Environmental Management 59(1): 47-69.

Magny M (2004) Holocene climate variability as reflected by mid-European lake-level fluctuations and its probable impact on prehistoric human settlements. The record of human/climate interaction in lake Sediments. Quaternary International 113(1): 65-79.

Magny M, Bossuet G, Ruffaldi P et al. (2011) Orbital imprint on Holocene palaeohydrological variations in west-central Europe as reflected by lake-level changes at Cerin (Jura Mountains, eastern France). Journal of Quaternary Science 26(2): 171177.

Markgraf V (1970) Palaeohistory of the spruce in Switzerland. Nature 228(5268) :249251.

Merkt J, Streif H (1970) Stechrohr-Bohrgeräte für limnische und marine Lockersedimente. Hannover: Geologisches Jahrbuch 88, 137-148.

MeteoSchweiz (2005) Klimadiagramme und -normwerte an Stationen. Available at: http://www.meteoschweiz.admin.ch/web/de/klima/klima_schweiz/klimadiagramme.htm 1. (Accessed 07 Oct 2013)

Molloy K, O'Connell M (1987) The nature of the vegetational changes at about 5000 B.P. with particular references to the elm decline: fresh evidence from Connemara, Western Ireland. New Phytologist 107(1): 203-220. 
Moore P, Webb J, Collinson M (1991) Pollen Analysis. Oxford: Blackwell Scientific Publications.

Parker AG, Goudie AS, Anderson DE et al. (2002) A review of the mid Holocene elm decline in the British Isles. Progress in Physical Geography 26(1): 1-45.

Perry I, Moore PD (1987) Dutch elm disease as an analogue of Neolithic elm decline. Nature 326(6108): 72-73.

R Development Core Team (2011) R: A language and environment for statistical computing. Vienna, Austria: R Foundation for Statistical Computing.

Ravazzi C (2002) Late Quaternary history of spruce in southern Europe. Review of Paleobotany and Palynology 120 : 131-170.

Reille M (1992) Pollen et spores d'Europe et d'Afrique du nord. Marseille: Laboratoire de Botanique Historique et Palynologie.

Reimer PJ, Bard E, Bayliss A et al. (2013) IntCal13 and Marine13 radiocarbon age calibration curves, 0-50,000 years cal BP. Radiocarbon 55(4): 1869-1887.

Renssen H, Seppä H, Crosta X et al. (2012) Global characterization of the Holocene thermal maximum. Quaternary Science Reviews 48: 7-19.

Rey F, Schwörer C, Gobet E et al. (2013) Climatic and human impacts on mountain vegetation at Lauenensee (Bernese Alps, Switzerland) during the last 14,000 years. The Holocene 23(10): 1415-1427.

Schoch W, Pawlik B, Schweingruber FH (1988) Botanische Makroreste: ein Atlas zur Bestimmung häufig gefundener und ökologisch wichtiger Pflanzensamen. Bern: Haupt.

Schwander J, Eicher U, Ammann B (2000) Oxygen isotopes of lake marl at Gerzensee and Leysin (Switzerland), covering the Younger Dryas and two minor oscillations, and their correlation to the GRIP ice core. Palaeogeography, Palaeoclimatology, Palaeoecology 159(3-4): 203-214.

Schwörer C, Colombaroli D, Kaltenrieder P et al. (2015) Early human impact (50003000 B.C.) affects mountain forest dynamics in the Alps. Journal of Ecology 103(2): 281-295. 
Schwörer C, Henne P, Tinner W (2014b) A model data comparison of Holocene timberline changes reveals past and future drivers of forest dynamics. Global Change Biology 20(5): 1512-1526.

Schwörer C, Kaltenrieder P, Glur L et al. (2014a) Holocene climate, fire and vegetation dynamics at the treeline in the Northwestern Swiss Alps. Vegetation History and Archaeobotany 23(5): 479-496.

Seppä H, Birks HJB (2001) July mean temperature and annual precipitation trends during the Holocene in the Fennoscandian tree-line area: pollen-based climate reconstructions. The Holocene 11(5): 527-539.

Seppä H, Alenius T, Bradshaw RHW et al. (2009) Invasion of Norway spruce (Picea abies) and the rise of the boreal ecosystem in Fennoscandia. Journal of Ecology 97(4): 629-640.

Stockmarr J (1971) Tablets with spores used in pollen analysis. Pollen et Spores 13: 615-621.

ter Braak CJF, Prentice IC (1988) A theory of gradient analysis. Advances in Ecological Research 18: 271-317.

ter Braak CJF, Šmilauer P (2002) CANOCO. Software for Canonical Community Ordination. Microcomputer Power, Ithaca, NY, USA.

Theurillat J, Guisan A (2001) Potential impact of Climate Change on vegetation in the European Alps: A review. Climatic Change 50: 77-109.

Tinner W, Ammann B (2005) Long-term responses of mountain ecosystems to environmental changes: resilience, adjustments, and vulnerability. In: Huber UM et al (eds.) Global Change and Mountain Regions: an overview of current knowledge.

Berlin: Springer.

Tinner W, Hu FS (2003) Size parameters, size-class distribution and area-number relationship of microscopic charcoal: relevance for fire reconstruction. The Holocene 13(4): 499-505.

Tinner W, Kaltenrieder P (2005) Rapid responses of high-mountain vegetation to early Holocene environmental changes in the Swiss Alps. Journal of Ecology 93(5): 936947. 
Tinner W, Lotter AF (2001) Central European vegetation response to abrupt climate change at $8.2 \mathrm{ka}$. Geology 29(6): 551-554.

Tinner W, Lotter AF (2006) Holocene expansion of Fagus silvatica and Abies alba in Central Europe: where are we after eight decades of debate? Quaternary Science Reviews 25(5-6): 526-549.

Tinner W, Theurillat J (2003) Uppermost limit, extent, and fluctuations of the timberline and treeline ecocline in the Swiss Central Alps during the past 11,500 years. Arctic, Antarctic and Alpine Research 35: 158-169.

Tinner W, Ammann B, Germann P (1996) Treeline fluctuations recorded for 12,500 years by soil profiles, pollen, and plant macrofossils in the Central Swiss Alps. Arctic and Alpine Research 28(2): 131-147.

Tinner W, Bigler C, Gedye S et al. (2008) A 700 year paleoecological record of boreal ecosystem responses to climatic variation from Alaska. Ecology 89(3): 729-743.

Tinner W, Colombaroli D, Heiri O et al. (2013) The past ecology of Abies alba provides new perspectives on future responses of silver fir forests to global warming. Ecological Monographs 83(4): 419-439.

Tinner W, Conedera M, Ammann B et al. (2005) Fire ecology north and south of the Alps since the last ice age. The Holocene 15(8): 1214-1226.

Tinner W, Conedera M, Gobet E et al. (2000) A palaeoecological attempt to classify fire sensitivity of trees in the Southern Alps. The Holocene 10(5): 565-574.

Tinner W, Hubschmid P, Wehrli M et al. (1999) Long-term forest fire ecology and dynamics in southern Switzerland. Journal of Ecology 87(2): 273-289.

Tinner W, Lotter AF, Ammann B et al. (2003) Climatic change and contemporaneous land-use phases north and south of the Alps 2300 BC to 800 AD. Quaternary Science Reviews 22(14): 1447-1460.

Trautmann W (1953) Zur Unterscheidung fossiler Spaltöffnungen der mitteleuropäischen Coniferen. Flora 140: 523-533. 
Valsecchi V, Carraro G, Conedera M et al. (2010) Late- Holocene vegetation and landuse dynamics in the Southern Alps (Switzerland) as a basis for nature protection and forest management. The Holocene 20(4): 483-495.

von Grafenstein U, Erlenkeuser H, Brauer A et al. (1999) A Mid-European Decadal Isotope-Climate Record from 15,500 to 5000 Years B.P. Science 284(5420): 16541657 .

Walter H (1974) Die Vegetation Osteuropas, Nord- und Zentralasiens. Stuttgart: G. Fischer Verlag.

Wanner H, Beer J, Bütikofer J et al. (2008) Mid- to Late Holocene climate change: an overview. Quaternary Science Reviews 27(19-20): 1791-1828.

Welten M (1952) Über die spät- und postglaziale Vegetationsgeschiche des Simmentals sowie die frühgeschichtliche und historische Wald- und Weiderodung auf Grund pollenanalytischer Untersuchungen. Bern: Verlag Hans Huber.

Welten M (1982) Vegetationsgeschichtliche Untersuchungen in den westlichen Schweizer Alpen. Bern-Wallis. Basel: Birkhäuser Verlag.

Wick L, van Leeuwen JFN, van der Knaap WO et al. (2003) Holocene vegetation development in the catchment of Sägistalsee (1935 m asl), a small lake in the Swiss Alps. Journal of Paleolimnology 30 (3): 261-272.

Wick L, Tinner W (1997) Vegetation changes and timberline fluctuations in the central Alps as indicators of Holocene climatic oscillations. Arctic and Alpine Research 29(4): 445-458.

Willis KJ, Birks HJB (2006) What is natural? The need for a long-term perspective in biodiversity conservation. Science 314(5803): 1261-1265.

Zoller H (1960) Pollenanalytische Untersuchungen zur Vegetationsgeschichte der insubrischen Schweiz. Denkschriften der Schweizerischen Naturforschenden Gesellschaft 83, 45-156. 
1

2

3

4

5

6

7

8

9

10

11

12
13

13
14

15

16

17

18

19

20

21

22

23

24

25

26

27

28

29

30

31

32

33

34

35

36

37

38

39

40

41

42

43

44

45

46

47

48

49

50

51

52

53

54

55

56

57

58

59

60

http://mc.manuscriptcentral.com/holocene 


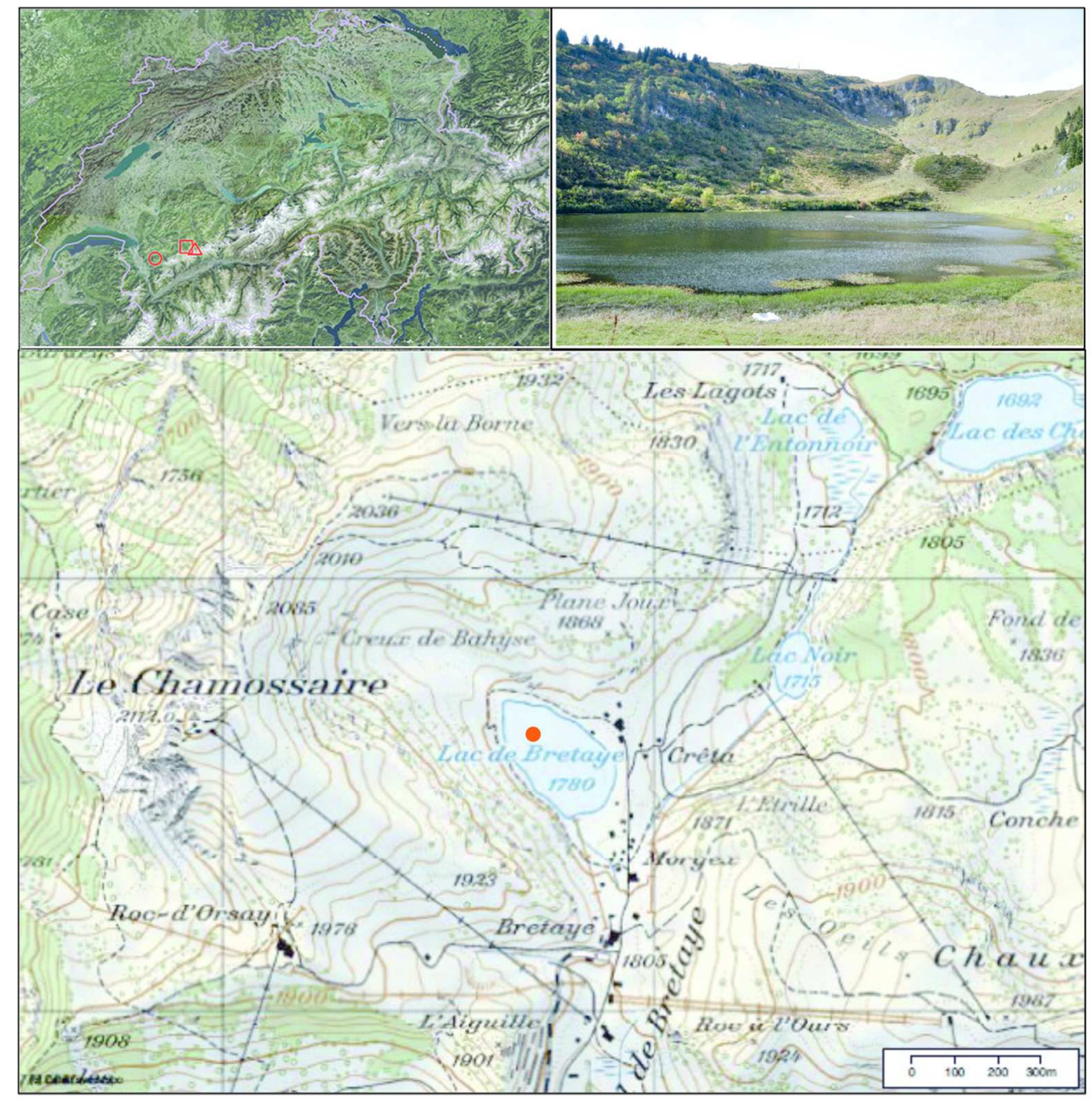

Figure 1: Top left: Map overview ( $\circ=$ Lac de Bretaye, $\Delta=$ Iffigsee, $\square=$ Lauenensee; (c) 2007 swisstopo). Top right: Photograph of Lac de Bretaye. Bottom: Map of Cal de Bretaye and its surroundings $(\bullet=$ coring site; reproduced by permission of swisstopo (BA15005), modified. $169 \times 176 \mathrm{~mm}(300 \times 300 \mathrm{DPI})$ 
Figure 2: Left: Age-depth model of the sediment calculated with clam 2.2 (Blaauw, 2010) from Lac de Bretaye with the calibrated ages and linear interpolation (black line) and 95\% confidence intervals (grey areas). Dashed lines are estimated ages and not based on radiocarbon dates. Right: Loss on ignition at $550^{\circ} \mathrm{C}$ as a proxy for sedimentary organic content. $161 \times 85 \mathrm{~mm}(300 \times 300$ DPI) 


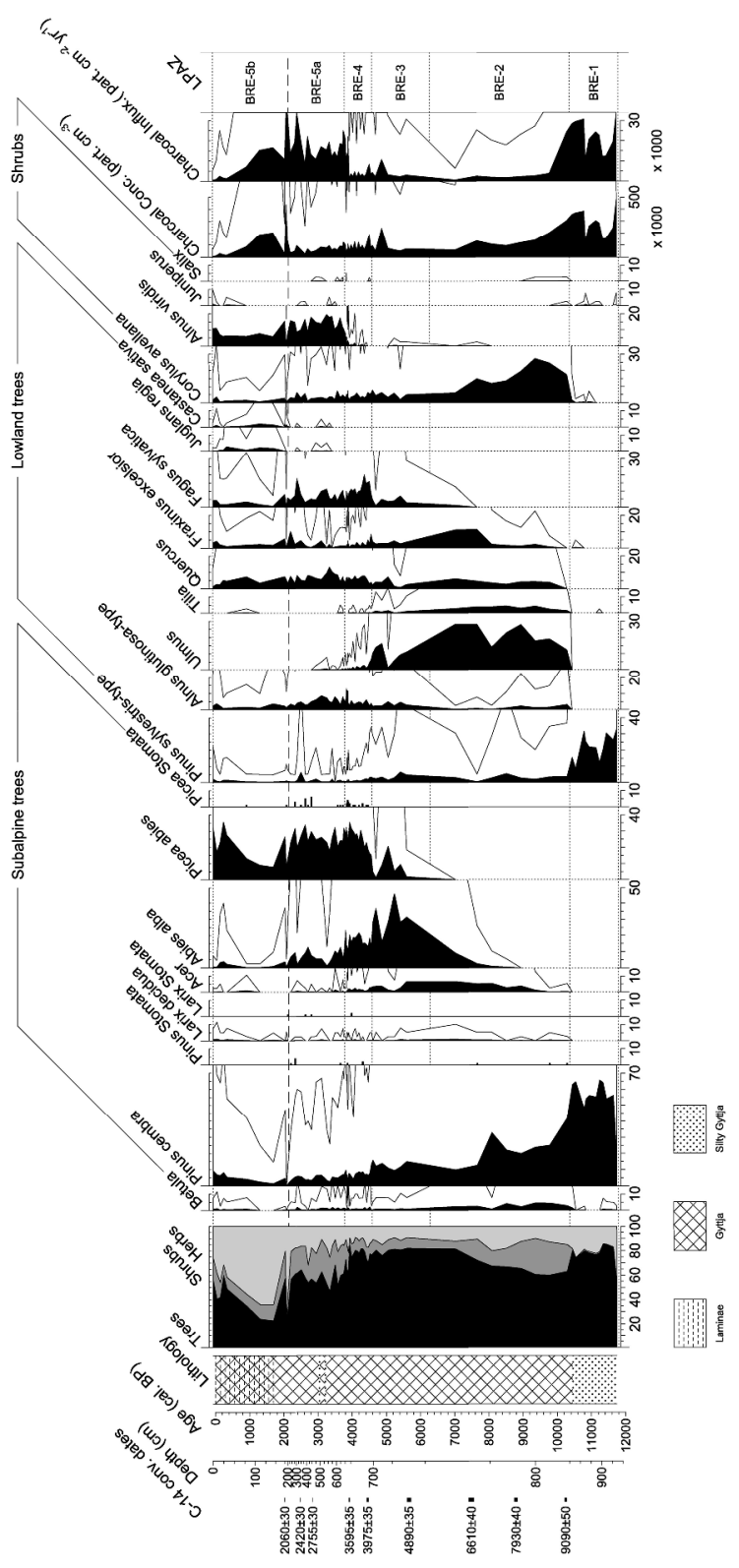

Figure 3: Selected pollen, spores and stomata percentages as well as lithology, microscopic charcoal concentrations and influx diagrams of Lac de Bretaye. Empty curves show 10x exaggeration. LPAZ local pollen assemblage zones. Analyst: Lena Thöle. $293 \times 629 \mathrm{~mm}(300 \times 300$ DPI $)$ 


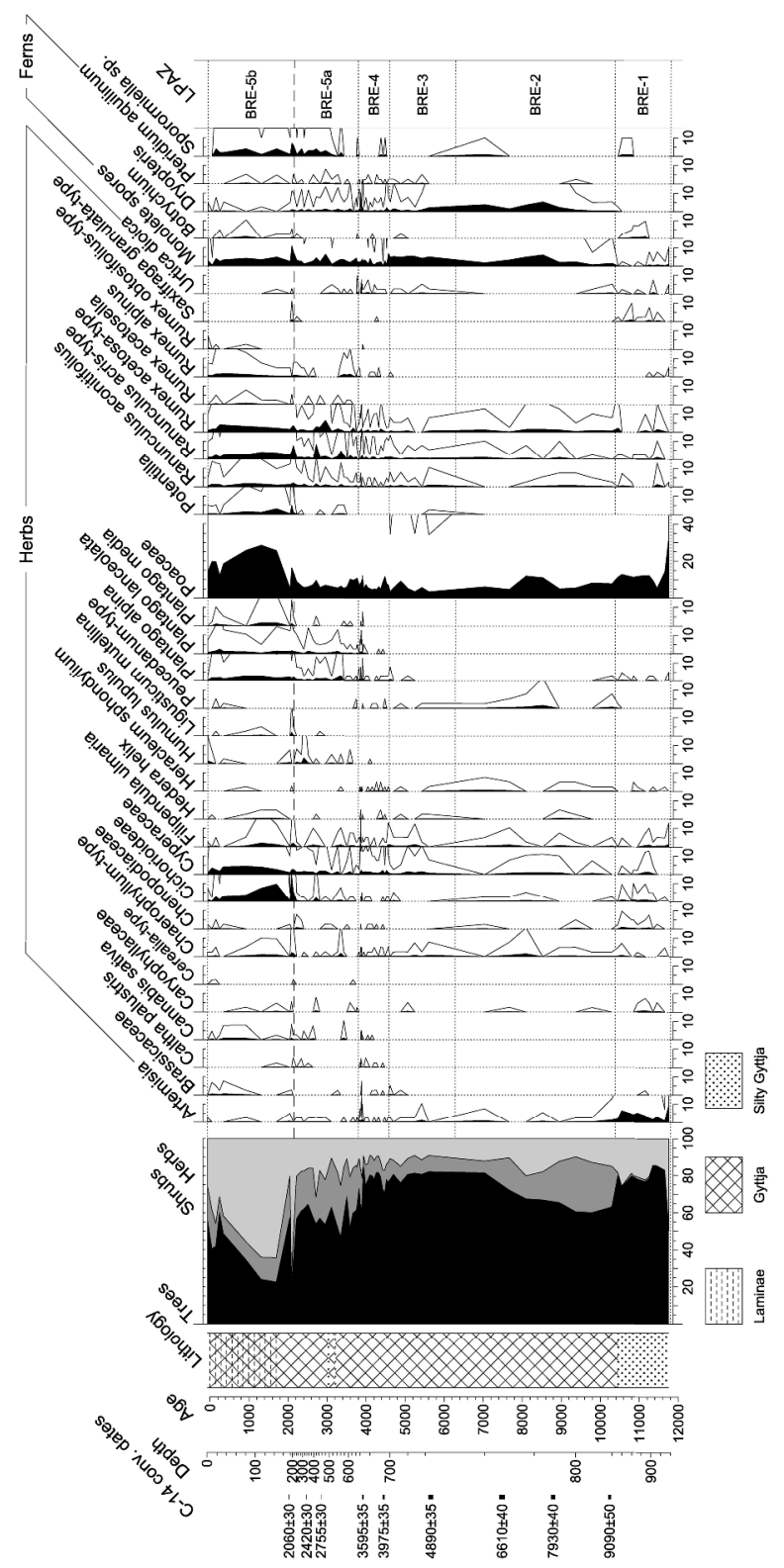

Figure 3 continued $293 \times 605 \mathrm{~mm}(300 \times 300$ DPI $)$ 
Figure 4: Macrofossil diagram of Lac de Bretaye. All values are standardized to $14 \mathrm{~cm}^{3}$ of volume. $\mathrm{F}$ fruits, $\mathrm{N}$ needles, S seeds, BS budscales, FS fruit scales, SH short shoots, LPAZ local pollen assemblage zones. Indet. antheres had no pollen and could not be identified. Analyst: Lena Thöle. $294 \times 644 \mathrm{~mm}(300 \times 300$ DPI $)$ 


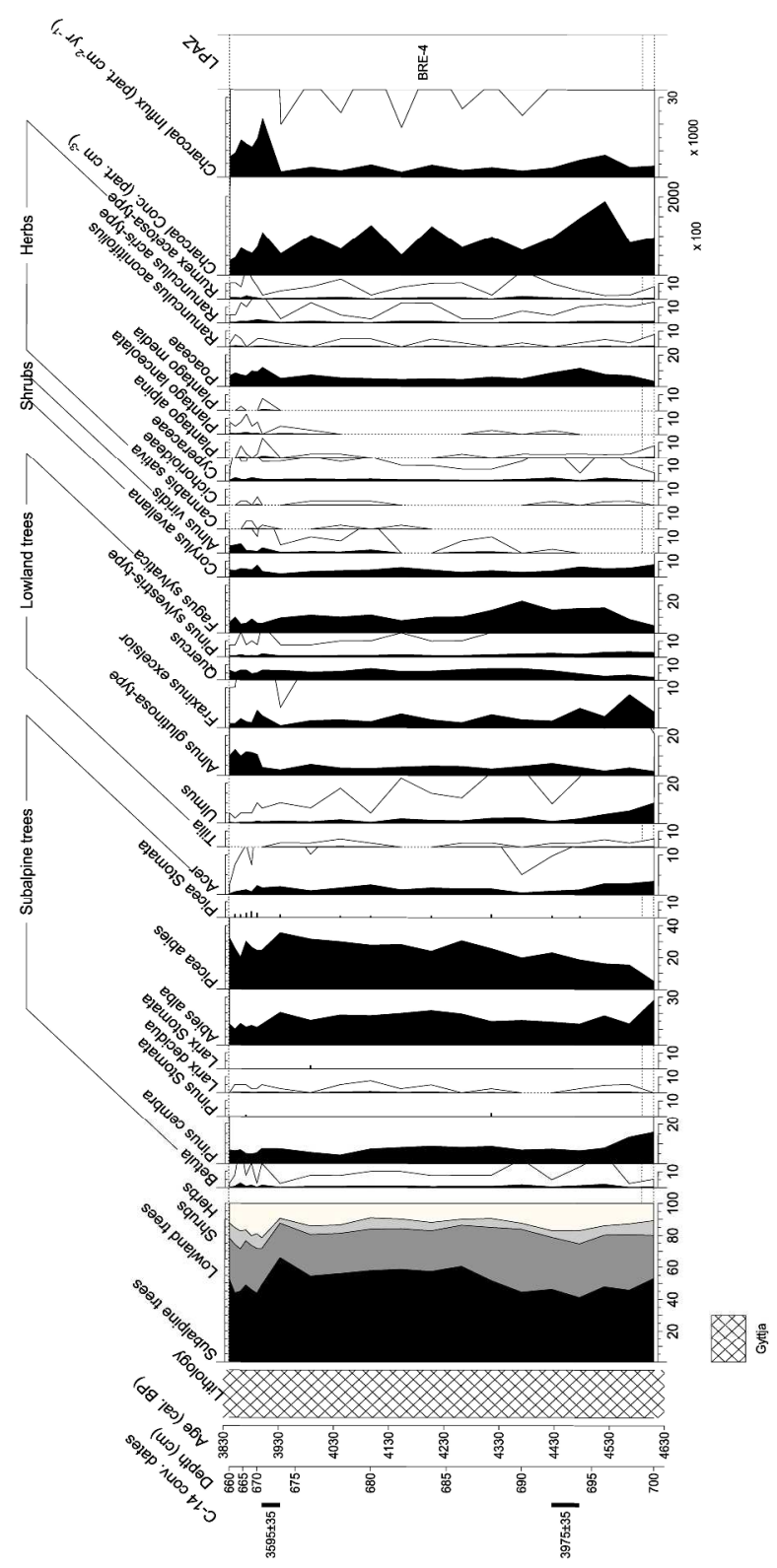

Figure 5: Pollen and stomata percentages as well as lithology, microscopic charcoal concentrations and influx values for the high-resolution sequence (4600-3850 cal. BP). Empty curves show 10x exaggeration. $293 \times 601 \mathrm{~mm}(300 \times 300 \mathrm{DPI})$ 

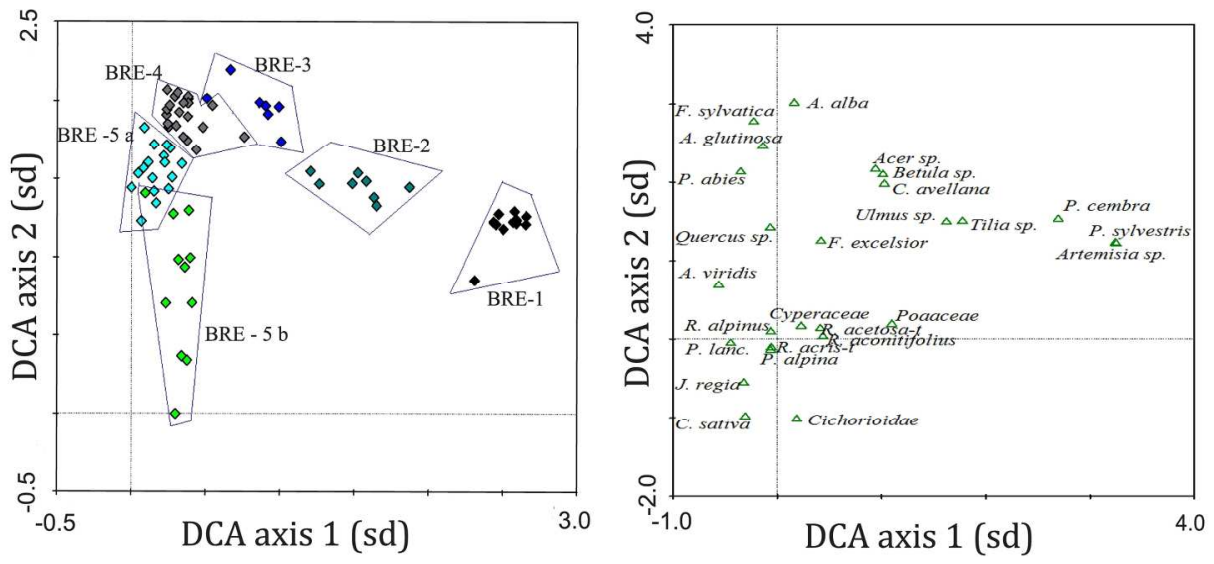

Figure 6: DCA scatterplots of samplse (left) and species (right) covering the entire Holocene. The first axis explains $29.4 \%$ of the variance in the data set and the second axis $13.3 \%$. The samples are grouped according to the local pollen assemblage zones (LPAZ). $197 \times 82 \mathrm{~mm}$ (300 x 300 DPI) 
Figure 7: Left: PCA scatterplot of species for the high-resolution sequence (LPAZ 4, 4600-3850 cal. BP). The first axis explains $51.5 \%$ of the variance in the dataset and the second axis $21.4 \%$. Right: hRDA-biplot of selected species and microscopic charcoal influx as a proxy for fire as explanatory variable. Axis 2 of the hRDA represents the residual variation not explained by fire.

$$
180 \times 99 \mathrm{~mm}(300 \times 300 \mathrm{DPI})
$$




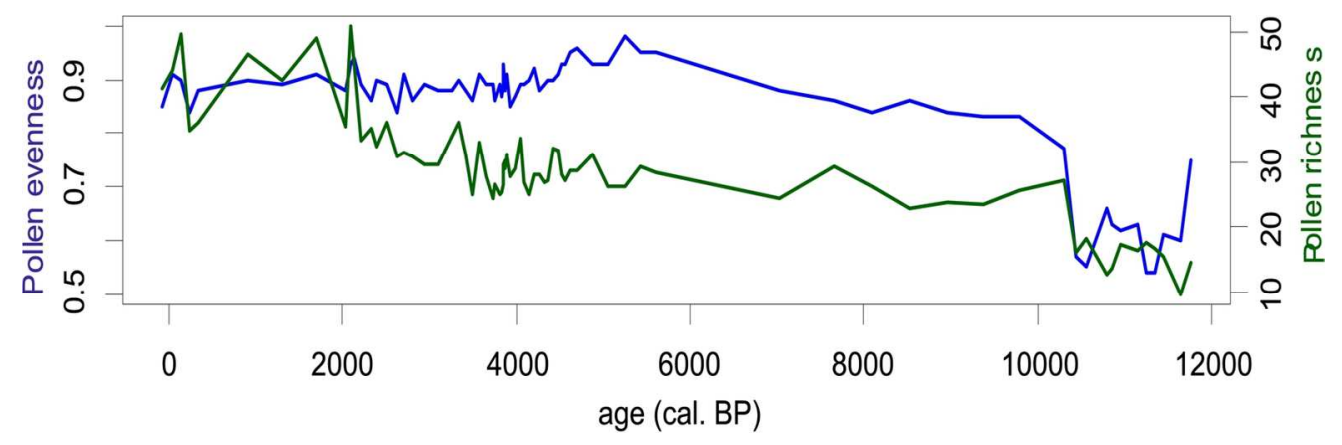

Figure 8: Comparison of palynological evenness (PIE, blue line) and richness (PRI, green line) estimated on a constant sum of 356 pollen grains.

$140 \times 44 \mathrm{~mm}(300 \times 300 \mathrm{DPI})$ 

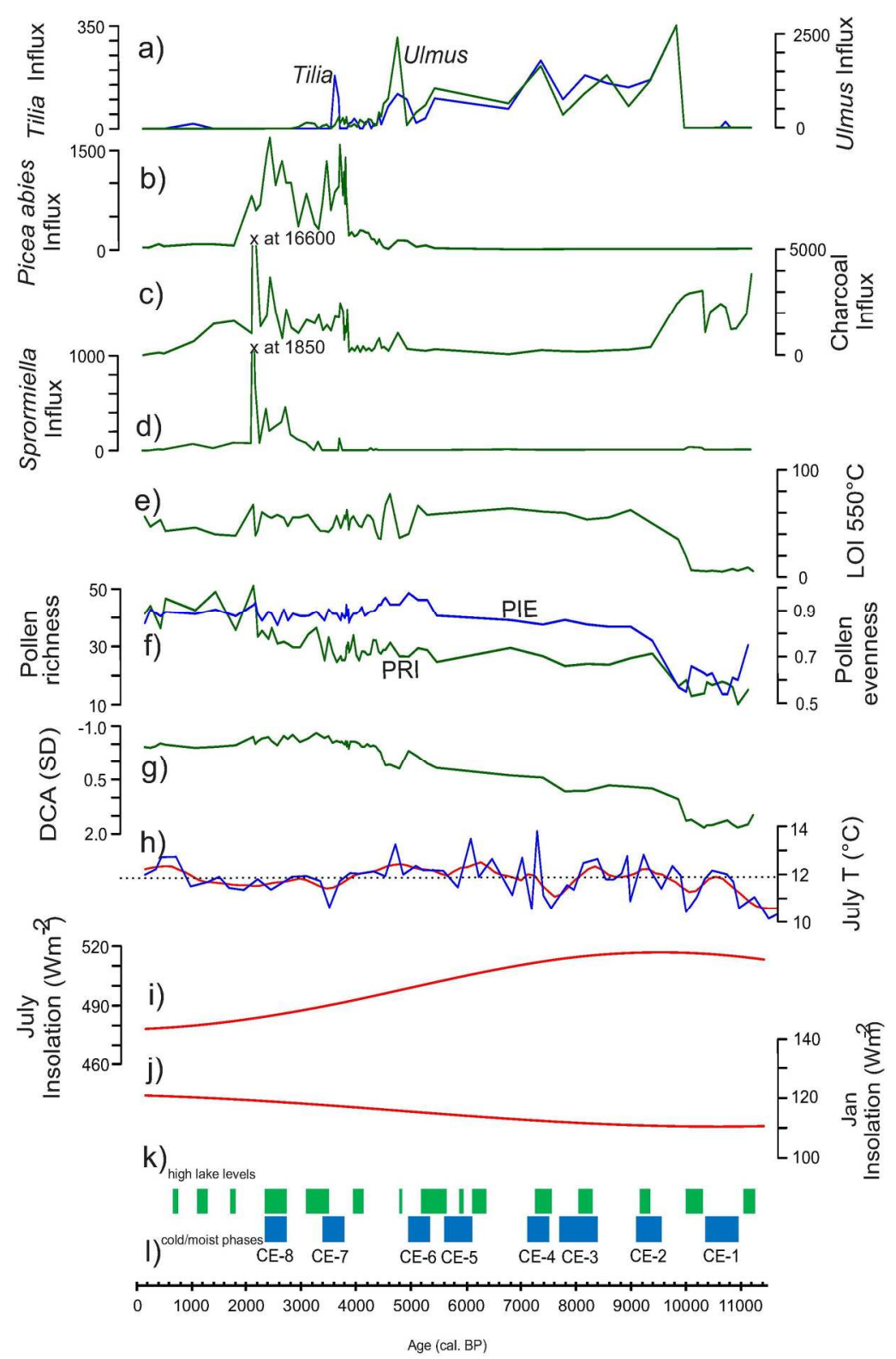

Figure 9: Comparison of biotic and abiotic proxies of Lac de Bretaye with different climate records. a) Pollen influx of Ulmus (green) and Tilia (blue). b) Pollen influx of Picea abies. c) Influx of microscopic charcoal. d) Influx of Sporormiella. e) Percentage of loss-on-ignition (LOI) at $550^{\circ} \mathrm{C}$ as a proxy for organic content of the sediment. f) Palynological richness (PRI, green) and pollen evenness (PIE, blue) as proxies for species diversity. g) DCA axis 1 sample scores. h) July temperature reconstruction based on a chironomid transfer function from Hinterburgseeli. The blue line is the unsmoothed temperature reconstruction, the red line the LOESS smoothed data, the dashed horizontal line the current mean July T (Heiri et al. 2003b). i) July and j) January solar insolation (Laskar et al. 2004). k) Periods of high lake levels after Magny (2004). I) Cold and wet phases identified from Central European pollen and macrofossil records (Haas et al. 1998). $153 \times 235 \mathrm{~mm}(300 \times 300 \mathrm{DPI})$ 
Table 1: Radiocarbon dates and calibrated ages with the program clam.

\begin{tabular}{|llllll|}
\hline Lab code & Depth (cm) & Material & ${ }^{14}$ C age & Age (cal. BP) & $\begin{array}{l}\text { Age (cal. BP, } \\
\text { 26 range) }\end{array}$ \\
\hline Poz-56708 & $170-172$ & Picea abies twig & $2060 \pm 30$ & 2032 & $1948-2116$ \\
Poz-53294 & 340 & Picea abies needle & $2420 \pm 30$ & 2472 & $2351-2696$ \\
Poz-56293 & 458 & Bark & $2755 \pm 30$ & 2845 & $2777-2924$ \\
Poz-53292 & $544-546$ & Picea abies seed and & $1920 \pm 35$ & rejected & rejected \\
Poz-53291 & $672-674$ & Wing, leaves & $3595 \pm 35$ & 3905 & $3780-4061$ \\
Poz-56707 & $692-694$ & Picea abies shoot & $3975 \pm 35$ & 4452 & $4299-4526$ \\
Poz-56706 & $744-746$ & Abies alba needle & $4890 \pm 35$ & 5626 & $5586-5709$ \\
Poz-53290 & $764-766$ & Pinus cembra needle & $6610 \pm 40$ & 7505 & $7437-7566$ \\
Poz-56705 & $788-790$ & Alnus twig & $7930 \pm 40$ & 8790 & $8632-8979$ \\
Poz-56703 & $816-818$ & Coniferous bark & $9090 \pm 50$ & 10263 & $10183-10391$ \\
\hline
\end{tabular}

20

21

22

23

24

25

26

27

28

29

30

31

32

33

34

35

36

37

38

39

40

41

42

43

44

45

46

47

48

49

50

51

52

53

54

55

56

57

58

59

60 